\title{
Research on physical activity levels of men at the age of fifty and over and comparison of some demographic data
}

\author{
Yunus OZTASYONAR', Sebnem SARVAN CENGIZ², Mehmet GULLU³, \\ Sefik OZBEK ${ }^{4}$, Muslum COLAK ${ }^{5}$
}

${ }^{1}$ Faculty of Sport Sciences, Atatürk University, Erzurum, Turkey.

${ }^{2}$ Department of Physical Education and Sport, Celal Bayar University, Manisa, Turkey.

3 Department of Physical Education and Sport, Inönü University, Malatya, Turkey.

${ }^{4}$ Physical Education Teacher, Turgut Özal Vocational and Technical Anatolian High School, Şanlıurfa, Turkey.

${ }^{5}$ Physical Education Teacher, Sarica Village Middle School, Sivas, Turkey.

Address Correspondence to S. Sarvan Cengiz, csebnem@gmail.com

\begin{abstract}
In this study, we aimed to research physical activity levels of men at the age of fifty and over. The population of study is Şanliurfa city and sample consists of men aged fifty and over in rest homes and coffee shops. 286 men have participated to this study from amongst the men in the locations stated. International Physical Activity Questionnaire, IPAQ, long form, has been used to analyze physical activity levels of men over the age of fifty. International validity and reliability studies have been implemented by Craig et al., and validity and reliability studies in Turkey have been implemented by Öztürk to university students. Blood pressure, length, weight, hip and waist circumferences have been measured for determining physical characteristics of men at the age over fifty who have participated to the study. Their BMIs have been calculated by using length ${ }^{2}$ / weight formula. Their hip and waist rates have been calculated from the formula developed by Garner et al. and Singh. In the analysis of the data obtained, \% frequency analysis and chi-square test have been applied. As the result of the study that we had implemented, a meaningful relationship has been found between marital status and AO values, education levels and Income levels and AO and MET values of older individuals. It has also been seen that there was a meaningful relationship between cigarette usage and waist circumference, and MET values similarly in respect of statistics.
\end{abstract}

Keywords: Elders, male, physical activity level.

\section{INTRODUCTION}

Old age is biological, chronological processes which have problems with its social aspects and is not possible to avert. The definition of old age is extensive and it is a concept in which changes and losses are seen in the individuals and includes socioeconomic, environmental, educational, and nutrition-related factors (3).

The lack of exercise and low physical compatibility level is a very important risk factor for illness and early deaths. It is found that regular physical activity prevents hypo kinetic diseases and early deaths due to these diseases, and provides a high quality life in respect of health (4). The studies which were implemented up to today show that some chronic diseases and death risk have decreased in adults who are physically active in high amounts. These diseases are hypertension (5), heart attack (6), colon and reproductive organs cancer (8), obesity and chronic back aches (5).

Physical Activity (PA) is effective in fit and joyful daily life, protecting the body against illnesses, preventing fatness by spending the excessive energy naturally, slowing aging and organic regression brought by aging, carrying respiratory and circulatory systems to higher capacity and protecting this capacity, decreasing neurotic tensions and increasing protective and preventive effect on death cases caused by coronary diseases, protecting the health and functionality of joint tissues connected to muscles, getting rid of loneliness by providing social cohesion and preventing stance disorders (9).

Physical activity is useful in every age. Regular physical activity can create important differences in healthy growth and development of children and young people, getting rid of unwanted bad habits, 
socializing, protecting adults from various chronic diseases or treatment or supporting the treatment of these diseases, providing elders to have an active old age period, in other words, increasing life quality in the entire lifetime (10). The studies show that physical activity is preponderantly related to all areas of life quality compared to other variables. Regular physical 2 activities support life quality by strengthening psychological wellness state and physical functionality (11).

WHO stated that most people in developed and developing counties live an inactive life, and inactive life is a health problem not mentioned sufficiently even though it is a serious problem (12).

With the advancing technology, it is known that individuals tend to sedentary life style. Industrialization and technological developments brought by urbanizing gradually increase inactivity and cause an increase in the tie spent in sedentary activities $(13,14,15)$.

With positive contributions of technological developments to life conditions and developments in health services, the rate of elder population to general population is gradually increasing throughout the world. With positive effects of education level of the society rising, the rate of elder population to general population increased and this case has caused new problems in societies. Aging of population is the main problem of many important ones for society. Especially, socio-economic conditions emerging with retirement negatively affect the elderly (16).

Providing elders to have an active old age, in other words, increasing life quality throughout the life, creates important differences. Physical performance is directly related to muscle strength, balance, walking speed and very important for elders' life quality and them to live independently (17). Positive effects of physical activity over health are stated often in literature. Especially many international and national health organizations state that regular physical activity is effective in solving obesity and chronic health problems (18). In addition to that, the changing living conditions, environmental, social elements, technology and food habits negatively affect physical activity levels of men over the age of fifty (19).

Today, living by increasing life quality has become an important subject such as living for a long time. Basic elements to age healthily and minimize health risks caused by the age with various methods are nutrition and physical activity (3). Unfortunately, physical activity levels of the individuals have decreased as negative effects of technological developments, and reached to a point that increases gradually throughout the world. Authorities accept that physical, mental illness and problems caused by inactive life are now at worrisome levels. Social cost level is gradually increasing because people are suffering and worry about productivity loss and health (18). Physical activity has many preventive and recuperative effects for many diseases (20).

According to "Chronic Diseases Risk Factors Study" implemented by Ministry of Health, it is determined that $87 \%$ of women and $77 \%$ of men throughout Turkey do not implement physical activities in sufficient levels. These rates reveal that inactive life style is a serious problem for our country (21).

With this research, when we consider age and body mass indexes, physical activity levels of men over the age of fifty and benefits of physical activities, it is aimed to encourage individuals for physical activity for a healthier society.

\section{MATERIAL \& METHOD}

In our study, we aimed to research physical activity levels of men at the age of fifty and over. Population of study is Şanlıurfa city men over the age of fifty, and sample consists of men aged fifty and over who spent time in rest homes and coffee shops. 286 voluntary men have participated to this study from amongst the men in the locations stated.

International Physical Activity Questionnaire, IPAQ, long form, has been used to analyze physical activity levels of men over the age of fifty. International validity and reliability studies have been implemented by Craig et al.(22), and validity and reliability studies in Turkey have been implemented by Öztürk (23) to university students. Length, weight, hip and waist circumferences of the men who have participated to the study have been measured for determining their physical characteristics, and their BMIs have been calculated by using (weight/length ${ }^{2}$ ) formula.Their hip and waist rates have been calculated from the formula developed by Singh (27), Garner et al. (13).

\section{Study model}

This study is a descriptive study which questions the existing situation. It is implemented in the form of relational screening model to review 
physical activity levels of men over the age of fifty who spend time in coffee shops and stay in rest homes in Şanlıurfa city. Data has been obtained from men over the age of fifty and cross-sectional research model is used.

\section{Study group}

Study group consists of 286 men over the age of fifty who stay in rest homes and spend time in coffee shops in Şanlıurfa City.

\section{Data gathering tools}

A questionnaire is used to gather data in this study. The questionnaire applied for study consists of two sections. First section of questionnaire form includes 11 questions which have demographic information of men over the age of fifty, and in the second section International Physical Activity Questionnaire, IPAQ, long form is used, which have been applied to university students by Craig et al. for international validity and reliability studies and Öztürk for validity and reliability studies in Turkey. This questionnaire provides information about time spent in sitting, walking, medium level intense activities and intense activities. International Physical Activity Questionnaire (IPAQ) has two form structure; short form and long form. Short form structure is designed for applying questionnaire by telephone and consists of 7 questions. Long form is developed for face to face questionnaire applications and consists of 27 questions. Since face to face questionnaire is applied in this study, long form has been used. Length, weight, hip and waist circumferences have been measured for determining physical characteristics of men at the age over fifty who have participated to the study.

\section{Data analysis}

In this study a statistics analysis has been implemented with SPSS-16 program to evaluate the data obtained. In the analysis of the data, \% frequency analysis and chi-square test have been applied.

\section{RESULTS}

According to Table 1, when the Abdominal Obesity Values pursuant to marital status of old individuals are considered, it has been seen that the highest percentages from married ones is "High risk group" AO with 39,2\% and again when marital status (married-single) is considered, the highest percentages are "High risk group" AO with 55,2\%. This case indicates that the marital status of old individuals effect on abdominal obesity.

When we look at Table 2, we can see that the highest abdominal obesity value percentages of whole age groups are "high $\mathrm{AO}^{\prime}$. However, in the comparison of $\mathrm{AO}$ value percentages of old individuals according to age groups, no meaningful significance was found $(p>0.05)$. This indicates that the age of elders does not affect $\mathrm{AO}$ values.

Table 1. Distribution of AO values according to marital status of old individuals.

\begin{tabular}{|c|c|c|c|c|c|c|c|c|c|c|}
\hline \multirow{3}{*}{ Marital Status } & \multicolumn{8}{|c|}{ Abdominal Obesity Values } & \multirow{2}{*}{\multicolumn{2}{|c|}{ Total }} \\
\hline & \multicolumn{2}{|c|}{ Perfect } & \multicolumn{2}{|c|}{ Good } & \multicolumn{2}{|c|}{ Mediocre } & \multicolumn{2}{|c|}{ High Risk Group } & & \\
\hline & $\mathrm{f}$ & $\%$ & $\mathrm{f}$ & $\%$ & $\mathrm{f}$ & $\%$ & $\mathrm{f}$ & $\%$ & $\mathrm{f}$ & $\%$ \\
\hline Married & 17 & 75 & 55 & 242 & 66 & 291 & 89 & 392 & 227 & 100 \\
\hline Single & 5 & 86 & 5 & 86 & 16 & 276 & 32 & 552 & 58 & 100 \\
\hline Total & 22 & 77 & 60 & 211 & 82 & 288 & 121 & 425 & 285 & 100 \\
\hline
\end{tabular}

Table 2. Distribution of AO values according to age old individuals.

\begin{tabular}{|c|c|c|c|c|c|c|c|c|c|c|}
\hline \multirow{3}{*}{ Age groups } & \multicolumn{8}{|c|}{ Abdominal Obesity Values } & \multirow{2}{*}{\multicolumn{2}{|c|}{ Total }} \\
\hline & \multicolumn{2}{|c|}{ Perfect } & \multicolumn{2}{|c|}{ Good } & \multicolumn{2}{|c|}{ Mediocre } & \multicolumn{2}{|c|}{ High Risk Group } & & \\
\hline & $\mathrm{f}$ & $\%$ & $\mathrm{f}$ & $\%$ & $\mathrm{f}$ & $\%$ & $\mathrm{f}$ & $\%$ & $\mathrm{f}$ & $\%$ \\
\hline Age 50-57 & 12 & 8.8 & 27 & 19.7 & 31 & 22.6 & 67 & 48.9 & 137 & 100 \\
\hline Age 58-65 & 5 & 5.7 & 21 & 23.9 & 32 & 36.4 & 30 & 34.1 & 88 & 100 \\
\hline Age 66-73 & 3 & 9.7 & 4 & 12.9 & 13 & 41.9 & 11 & 35.5 & 31 & 100 \\
\hline Age 74-81 & 2 & 8.7 & 8 & 34.8 & 4 & 17.4 & 9 & 39.1 & 23 & 100 \\
\hline Age 82 and over & 0 & 0.0 & 0 & 0.0 & 2 & 33.3 & 4 & 66.7 & 6 & 100 \\
\hline Total & 22 & 7.7 & 60 & 21.1 & 82 & 28.8 & 121 & 42.5 & 285 & 100 \\
\hline
\end{tabular}


According to Table 3, when we look at Abdominal Obesity Values of elders pursuant to their education levels, it has been seen that the highest percentage of individuals who are not literate is "High risk Group" with $34.0 \%(\mathrm{n}=35)$, and again when we look at individuals who have graduated from primary school, the highest percentage is "High risk Group" with $51,1 \%(n=48)$, and when we look at individuals who have graduated from secondary school and high school, the highest percentage is "High risk Group" with $48.5 \%(\mathrm{n}=33)$, and when we look at individuals who have graduated from university, the highest percentage is "Mediocre" AO with $45.9 \%(\mathrm{n}=9)$. A meaningful significance is found in the statistical comparison implemented between $\mathrm{AO}$ value percentages according to their education levels $(\mathrm{p}<0.05)$.

According to Table 4, when we look at Abdominal Obesity Values of elders pursuant to number of their children, it has been seen that the highest percentage of individuals who do not have children is "High risk Group" AO with $47.4 \%$ (n=9), and again when we look at individuals who have 12 children, the highest percentage is "High risk Group" AO with $44.4 \%(\mathrm{n}=12)$, and when we look at individuals who have 3-4 children, the highest percentage is "High risk Group" AO with 46.7\% $(n=28)$, and when we look at individuals who have more than 5 children, the highest percentage is "High Risk Group" AO with 40,2\% (n=72). No meaningful significance is found statistically between $\mathrm{AO}$ values and number of children.
According to Table 5, when we look at Abdominal Obesity Values of elders pursuant to their income status, it has been seen that the individuals who receive a salary in the amount of 0500 TL the highest percentage is "High risk Group" $\mathrm{AO}$ with $46.9 \%(\mathrm{n}=23)$, and again when we look at individuals who receive salary in the amount between 501-999 $\mathrm{tl}$, the highest percentage is "Mediocre" AO with 34.5\% ( $\mathrm{n}=30)$, and when we look at individuals who receive a salary in the amount between 1000-1499 $\mathrm{tl}$, the highest percentage is "Mediocre" AO with $38.0 \%(n=19)$, and when we look at individuals who receive a salary between 1500-1999 tl, the highest percentage is "High Risk Group" AO with $44.7 \%$ ( $\mathrm{n}=17)$, when we look at individuals who receive a salary in the amount 2000 tl and over, the highest percentage is "High Risk Group" AO with $72.1 \% \quad(\mathrm{n}=44)$. A meaningful significance is found in the statistical comparison implemented between $\mathrm{AO}$ value percentages according to their income status.

According to Table 6, when we look at the distributions of Abdominal Obesity Values of elders pursuant to their smoking habits, it has been seen that in the case of individuals who smoke, the highest percentage is "High risk Group" AO with $38.8 \%(\mathrm{n}=54)$, and again in the case of non-smoking individuals, the highest percentage is "High Risk Group" AO with $45.9 \%$ ( $\mathrm{n}=67)$. No meaningful significance is found statistically when smoking habits and $\mathrm{AO}$ values of the old individuals are reviewed according to table.

Table 3. Distribution of AO values according to education levels of old individuals.

\begin{tabular}{|c|c|c|c|c|c|c|c|c|c|c|}
\hline \multirow{3}{*}{ Education Levels } & \multicolumn{8}{|c|}{ Abdominal Obesity Values } & \multirow{2}{*}{\multicolumn{2}{|c|}{ Total }} \\
\hline & \multicolumn{2}{|c|}{ Perfect } & \multicolumn{2}{|c|}{ Good } & \multicolumn{2}{|c|}{ Mediocre } & \multicolumn{2}{|c|}{ High Risk Group } & & \\
\hline & $\mathrm{f}$ & $\%$ & $\mathrm{f}$ & $\%$ & $\mathrm{f}$ & $\%$ & $\mathrm{f}$ & $\%$ & $\mathrm{f}$ & $\%$ \\
\hline Not Literate & 11 & 10.7 & 30 & 29.1 & 27 & 26.2 & 35 & 34.0 & 103 & 100 \\
\hline Primary School & 9 & 9.6 & 14 & 14.9 & 23 & 24.5 & 48 & 51.1 & 94 & 100 \\
\hline Secondary School and High School & 2 & 2.9 & 10 & 14.7 & 23 & 33.8 & 33 & 48.5 & 68 & 100 \\
\hline University & 0 & 0.0 & 6 & 30.0 & 9 & 45.0 & 5 & 25.0 & 20 & 100 \\
\hline Total & 22 & 7.7 & 60 & 21.1 & 82 & 28.8 & 121 & 42.5 & 285 & 100 \\
\hline
\end{tabular}

Table 4. Distribution of AO values according to number of children of old individuals.

\begin{tabular}{|c|c|c|c|c|c|c|c|c|c|c|}
\hline \multirow{3}{*}{ Number of Children } & \multicolumn{8}{|c|}{ Abdominal Obesity Values } & \multirow{2}{*}{\multicolumn{2}{|c|}{ Total }} \\
\hline & \multicolumn{2}{|c|}{ Perfect } & \multicolumn{2}{|c|}{ Good } & \multicolumn{2}{|c|}{ Mediocre } & \multicolumn{2}{|c|}{ High Risk Group } & & \\
\hline & $\mathrm{f}$ & $\%$ & $\mathrm{f}$ & $\%$ & $\mathrm{f}$ & $\%$ & $\mathrm{~F}$ & $\%$ & $\mathrm{f}$ & $\%$ \\
\hline No Children & 1 & 5.3 & 4 & 21.1 & 5 & 26.3 & 9 & 47.4 & 19 & 100 \\
\hline 1-2 Children & 3 & 11.1 & 3 & 11.1 & 9 & 33.3 & 12 & 44.4 & 27 & 100 \\
\hline 3-4 Children & 7 & 11.7 & 9 & 15.0 & 16 & 26.7 & 28 & 46.7 & 60 & 100 \\
\hline 5 Children and More & 11 & 6.1 & 44 & 24.6 & 52 & 29.1 & 72 & 40.2 & 179 & 100 \\
\hline Total & 22 & 7.7 & 60 & 21.1 & 82 & 28.8 & 121 & 42.5 & 285 & 100 \\
\hline
\end{tabular}


Table 5. Distribution of $\mathrm{AO}$ values according to income status of old individuals.

\begin{tabular}{|c|c|c|c|c|c|c|c|c|c|c|}
\hline \multirow{3}{*}{ Income Status } & \multicolumn{8}{|c|}{ Abdominal Obesity Values } & \multirow{2}{*}{\multicolumn{2}{|c|}{ Total }} \\
\hline & \multicolumn{2}{|c|}{ Perfect } & \multicolumn{2}{|c|}{ Good } & \multicolumn{2}{|c|}{ Mediocre } & \multicolumn{2}{|c|}{ High Risk Group } & & \\
\hline & $\mathrm{f}$ & $\%$ & $\mathrm{f}$ & $\%$ & $\mathrm{f}$ & $\%$ & $\mathrm{f}$ & $\%$ & $\mathrm{f}$ & $\%$ \\
\hline $0-500$ tl & 6 & 12.2 & 8 & 16.3 & 12 & 24.5 & 23 & 46.9 & 49 & 100 \\
\hline 501-999tl & 11 & 12.6 & 25 & 28.7 & 30 & 34.5 & 21 & 24.1 & 87 & 100 \\
\hline 1000-1499tl & 5 & 10.0 & 10 & 20.0 & 19 & 38.0 & 16 & 32.0 & 50 & 100 \\
\hline 1500-1999tl & 0 & 0.0 & 11 & 28.9 & 10 & 26.3 & 17 & 44.7 & 38 & 100 \\
\hline 2000 and Over & 0 & 0.0 & 6 & 9.8 & 11 & 18.0 & 44 & 72.1 & 61 & 100 \\
\hline Total & 22 & 7.7 & 60 & 21.1 & 82 & 28.8 & 121 & 42.5 & 285 & 100 \\
\hline
\end{tabular}

Table 6. Distribution of AO values according to smoking habits of old individuals.

\begin{tabular}{|c|c|c|c|c|c|c|c|c|c|c|}
\hline \multirow{3}{*}{$\begin{array}{l}\text { Smoking } \\
\text { Habits }\end{array}$} & \multicolumn{8}{|c|}{ Abdominal Obesity Values } & \multirow{2}{*}{\multicolumn{2}{|c|}{ Total }} \\
\hline & \multicolumn{2}{|c|}{ Perfect } & \multicolumn{2}{|c|}{ Good } & \multicolumn{2}{|c|}{ Mediocre } & \multicolumn{2}{|c|}{ High Risk Group } & & \\
\hline & $\mathrm{f}$ & $\%$ & $\mathrm{f}$ & $\%$ & $\mathrm{f}$ & $\%$ & $\mathrm{f}$ & $\%$ & $\mathrm{f}$ & $\%$ \\
\hline Smokers & 9 & 6.5 & 34 & 24.5 & 42 & 30.2 & 54 & 38.8 & 139 & 100 \\
\hline Non-smokers & 13 & 8.9 & 26 & 17.8 & 40 & 27.4 & 67 & 45.9 & 146 & 100 \\
\hline Total & 22 & 7.7 & 60 & 21.1 & 82 & 28.8 & 121 & 42.5 & 285 & 100 \\
\hline
\end{tabular}

Table 7. Distribution of MET values according to marital status of old individuals.

\begin{tabular}{|c|c|c|c|c|c|c|c|c|}
\hline \multirow{3}{*}{ Marital Status } & \multicolumn{6}{|c|}{ MET Values } & & \\
\hline & \multicolumn{2}{|c|}{ Inactive } & \multicolumn{2}{|c|}{ Mediocre } & \multicolumn{2}{|c|}{ Active } & \multicolumn{2}{|c|}{ Total } \\
\hline & $\mathrm{f}$ & $\%$ & $\mathrm{f}$ & $\%$ & $\mathrm{f}$ & $\%$ & $\mathrm{f}$ & $\%$ \\
\hline Married & 7 & 3.1 & 37 & 16.3 & 183 & 80.6 & 227 & 100 \\
\hline Single & 1 & 1.7 & 8 & 13.8 & 49 & 84.5 & 58 & 100 \\
\hline Total & 8 & 2.8 & 45 & 15.8 & 232 & 81.4 & 285 & 100 \\
\hline
\end{tabular}

According to Table 7, when we look at MET (Physical activity level) values of old individuals pursuant to their marital status, it has been seen that in the case of married individuals, the highest percentage is "Active" MET with $80.6 \%(\mathrm{n}=183)$, and again in the case of single individuals, the highest percentage is "Active" MET with $84.8 \%$ ( $\mathrm{n}=49$ ). A meaningful significance is found in the statistical comparison implemented between MET value percentages according to their marital status.

According to Table 8, when we look at MET (physical activity level) of elders pursuant to their age groups, it has been seen that the individuals who are between 50-57 years old, the highest percentage is "Active" MET with $82.5 \%(\mathrm{n}=113)$, and again when we look at individuals who are between 58-65 years old, the highest percentage is "Active" MET with $85,2 \% \quad(n=75)$, and when we look at individuals who are between 66-73 years old, the highest percentage is "Active" MET with 80.6\% $(n=25)$, and when we look at individuals who are between 74-81 years old, the highest percentage is "Active" MET with 60.9\% ( $\mathrm{n}=14)$, when we look at individuals who are 82 years old and over, the highest percentage is "Active" MET with 83.3\% $(n=5)$. No meaningful significance is found statistically in the comparison of MET values pursuant to age groups according to table.

According to Table 9, when we look at MET (physical activity level) Values of elders pursuant to their education levels, it has been seen that the highest percentages of individuals who are not literate is "Active" MET with $75.7 \%$ ( $\mathrm{n}=78)$, and again when we look at individuals who have graduated from primary school, the highest percentage is "Active" MET with 93.6\% ( $\mathrm{n}=88$ ), and when we look at individuals who have graduated from secondary school and high school, the highest percentage is "Active" MET with $77.9 \%(\mathrm{n}=53)$, and when we look at individuals who have graduated from university, the highest percentage is "Active" MET with $65.0 \% \quad(\mathrm{n}=13)$. Accordingly, no meaningful significance is found statistically in the comparison of MET values pursuant to education level of individuals. 
Table 8. Distribution of MET values according to age of old individuals.

\begin{tabular}{|c|c|c|c|c|c|c|c|c|}
\hline \multirow{3}{*}{ Age groups } & \multicolumn{6}{|c|}{ MET Values } & & \\
\hline & \multicolumn{2}{|c|}{ Inactive } & \multicolumn{2}{|c|}{ Mediocre } & \multicolumn{2}{|c|}{ Active } & \multicolumn{2}{|c|}{ Total } \\
\hline & $\mathrm{f}$ & $\%$ & $\mathrm{f}$ & $\%$ & $\mathrm{f}$ & $\%$ & $\mathrm{f}$ & $\%$ \\
\hline Age 50-57 & 4 & 2.9 & 20 & 14.6 & 113 & 82.5 & 137 & 100 \\
\hline Age 58-65 & 1 & 1.1 & 12 & 13.6 & 75 & 85.2 & 88 & 100 \\
\hline Age 66-73 & 0 & 0 & 6 & 19.4 & 25 & 80.6 & 31 & 100 \\
\hline Age 74-81 & 2 & 8.7 & 7 & 30.4 & 14 & 60.9 & 23 & 100 \\
\hline 82 and Over & 1 & 16.7 & 0 & 0 & 5 & 83.3 & 6 & 100 \\
\hline Total & 8 & 2.8 & 45 & 15.8 & 232 & 81.4 & 285 & 100 \\
\hline
\end{tabular}

Table 9. Distribution of MET values according to education levels of old individuals.

\begin{tabular}{|c|c|c|c|c|c|c|c|c|}
\hline \multirow{3}{*}{ Education Level } & \multicolumn{6}{|c|}{ MET Values } & \multirow{2}{*}{\multicolumn{2}{|c|}{ Total }} \\
\hline & \multicolumn{2}{|c|}{ Inactive } & \multicolumn{2}{|c|}{ Mediocre } & \multicolumn{2}{|c|}{ Active } & & \\
\hline & $\mathrm{f}$ & $\%$ & $\mathrm{f}$ & $\%$ & $\mathrm{f}$ & $\%$ & $\mathrm{f}$ & $\%$ \\
\hline Not literate & 4 & 3.9 & 21 & 20.4 & 78 & 75.7 & 103 & 100 \\
\hline Primary school & 9 & 0 & 6 & 6.4 & 88 & 93.6 & 94 & 100 \\
\hline Secondary school and high school & 4 & 5.9 & 11 & 16.2 & 53 & 77.9 & 68 & 100 \\
\hline University & 0 & 0 & 7 & 35.0 & 13 & 65.0 & 20 & 100 \\
\hline Total & 8 & 2.8 & 45 & 15.8 & 232 & 81.481 .4 & 285 & 100 \\
\hline
\end{tabular}

Table 10. Distribution of MET values according to number of children of old individuals.

\begin{tabular}{|c|c|c|c|c|c|c|c|c|}
\hline \multirow{3}{*}{ Number of Children } & \multicolumn{6}{|c|}{ MET Values } & \multirow{2}{*}{\multicolumn{2}{|c|}{ Total }} \\
\hline & \multicolumn{2}{|c|}{ Inactive } & \multicolumn{2}{|c|}{ Mediocre } & \multicolumn{2}{|c|}{ Active } & & \\
\hline & $\mathrm{f}$ & $\%$ & $\mathrm{f}$ & $\%$ & $\mathrm{f}$ & $\%$ & $\mathrm{f}$ & $\%$ \\
\hline No children & 0 & 0 & 5 & 26.3 & 14 & 73.7 & 19 & 100 \\
\hline 1-2 children & 1 & 3.7 & 1 & 3.7 & 25 & 92.6 & 27 & 100 \\
\hline 3-4 children & 2 & 3.3 & 7 & 11.7 & 51 & 85.0 & 60 & 100 \\
\hline 5 children and more & 5 & 2.8 & 32 & 17.9 & 142 & 79.3 & 179 & 100 \\
\hline Total & 8 & 2.8 & 45 & 15.8 & 232 & 81.4 & 285 & 100 \\
\hline
\end{tabular}

According to Table 10, when we look at MET (physical activity level) Values of elders pursuant to number of children, it has been seen that the highest percentages of individuals who do not have children is "Active" MET with 73.7\% ( $\mathrm{n}=14)$, and again when we look at individuals who have 1-2 children, the highest percentage is "Active" MET with $92.6 \%$ $(\mathrm{n}=25)$, and when we look at individuals who have 3-4 children, the highest percentage is "Active" MET with $85.0 \%(\mathrm{n}=51)$, and when we look at individuals who have 5 and more children, the highest percentage is "Active" MET with 79.3\% ( $\mathrm{n}=142)$. Accordingly, no meaningful significance is found statistically in the comparison of MET values pursuant to number of children of individuals.

According to Table 11, when we look at MET (physical activity level) Values of elders pursuant to their income status, it has been seen that the highest percentage of individuals who receive a salary in the amount of $0-500$ TL is "Active" MET with $87,8 \%$ $(n=43)$, and again when we look at individuals who receive salary in the amount between 501-999 $\mathrm{tl}$, the highest percentage is "Active" MET with $72.4 \%$ $(n=63)$, and when we look at individuals who receive a salary in the amount between 1000-1499 tl, the highest percentage is "Active" MET with $80.0 \%$ $(n=40)$, and when we look at individuals who receive a salary between 1500-1999 $\mathrm{tl}$, the highest percentage is "Active" MET with $78.9 \% \quad(\mathrm{n}=30)$, when we look at individuals who receive a salary in the amount $2000 \mathrm{tl}$ and over, the highest percentage is "Active" MET with $91.8 \%(\mathrm{n}=56)$. A meaningful significance $(p<0.05)$ is found in the statistical comparison implemented between MET value percentages according to their income status. 
Table 11. Distribution of MET values according to income status of old individuals.

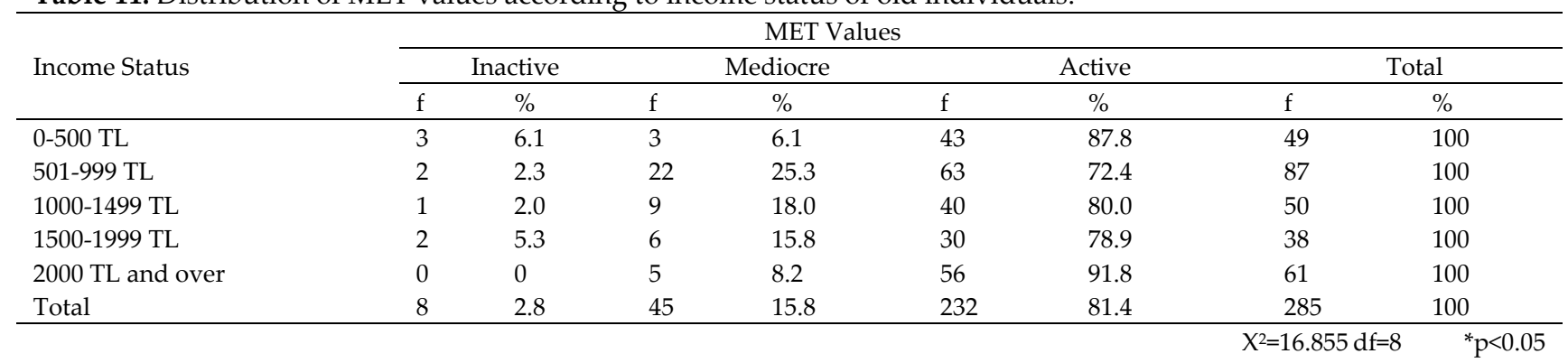

Table 12. Distribution of MET values according to smoking habits of old individuals.

\begin{tabular}{|c|c|c|c|c|c|c|c|c|}
\hline \multirow{3}{*}{ Smoking Habits } & \multicolumn{6}{|c|}{ MET Values } & & \\
\hline & \multicolumn{2}{|c|}{ Inactive } & \multicolumn{2}{|c|}{ Mediocre } & \multicolumn{2}{|c|}{ Active } & \multicolumn{2}{|c|}{ Total } \\
\hline & $\mathrm{f}$ & $\%$ & $\mathrm{f}$ & $\%$ & $\mathrm{f}$ & $\%$ & $\mathrm{f}$ & $\%$ \\
\hline Smokers & 1 & 0.7 & 31 & 22.3 & 107 & 77.0 & 139 & 100 \\
\hline Non-smokers & 7 & 4.8 & 14 & 9.6 & 125 & 85.6 & 146 & 100 \\
\hline Total & 8 & 2.8 & 45 & 15.8 & 232 & 81.4 & 285 & 100 \\
\hline
\end{tabular}

Table 13. Distribution of MET values according to waist circumferences of old individuals.

\begin{tabular}{|c|c|c|c|c|c|c|c|c|}
\hline \multirow{3}{*}{ Waist Circumferences } & \multicolumn{6}{|c|}{ MET Values } & & \\
\hline & \multicolumn{2}{|c|}{ Inactive } & \multicolumn{2}{|c|}{ Mediocre } & \multicolumn{2}{|c|}{ Active } & \multicolumn{2}{|c|}{ Total } \\
\hline & $\mathrm{f}$ & $\%$ & $\mathrm{f}$ & $\%$ & $\mathrm{f}$ & $\%$ & $\mathrm{f}$ & $\%$ \\
\hline Normal & 4 & 2.6 & 36 & 23.5 & 113 & 73.9 & 153 & 100 \\
\hline Illness Risk & 4 & 3.0 & 9 & 6.8 & 119 & 90.2 & 132 & 100 \\
\hline Total & 8 & 2.8 & 45 & 15.8 & 232 & 81.4 & 285 & 100 \\
\hline
\end{tabular}

Table 14. Distribution of MET values according to hip circumferences of old individuals.

\begin{tabular}{|c|c|c|c|c|c|c|c|c|}
\hline \multirow{3}{*}{ Hip Circumference Measurements } & \multicolumn{6}{|c|}{ MET Values } & & \\
\hline & \multicolumn{2}{|c|}{ Inactive } & \multicolumn{2}{|c|}{ Mediocre } & \multicolumn{2}{|c|}{ Active } & \multicolumn{2}{|c|}{ Total } \\
\hline & $\mathrm{f}$ & $\%$ & $\mathrm{f}$ & $\%$ & $\mathrm{f}$ & $\%$ & $\mathrm{f}$ & $\%$ \\
\hline $44-48 \mathrm{~cm}$ & 0 & 0 & 8 & 8.9 & 82 & 91.1 & 90 & 100 \\
\hline $89-133 \mathrm{~cm}$ & 8 & 4.3 & 37 & 19.7 & 143 & 76.1 & 188 & 100 \\
\hline $134-178 \mathrm{~cm}$ & 0 & 0 & 0 & 0 & 5 & 100 & 5 & 100 \\
\hline $179-223 \mathrm{~cm}$ & 0 & 0 & 0 & 0 & 2 & 100 & 2 & 100 \\
\hline Total & 8 & 2.8 & 45 & 15.8 & 232 & 81.4 & 285 & 100 \\
\hline
\end{tabular}

Table 15. Distribution of MET values according to body mass indexes bmi of old individuals.

\begin{tabular}{|c|c|c|c|c|c|c|c|c|}
\hline \multirow{3}{*}{ BMI } & \multicolumn{6}{|c|}{ MET Values } & & \\
\hline & \multicolumn{2}{|c|}{ Inactive } & \multicolumn{2}{|c|}{ Mediocre } & \multicolumn{2}{|c|}{ Active } & \multicolumn{2}{|c|}{ Total } \\
\hline & $\mathrm{f}$ & $\%$ & $\mathrm{f}$ & $\%$ & $\mathrm{f}$ & $\%$ & $\mathrm{f}$ & $\%$ \\
\hline Thin & 0 & 0 & 0 & 0 & 1 & 100 & 1 & 100 \\
\hline Normal Weight & 3 & 4.1 & 7 & 9.5 & 64 & 86.5 & 74 & 100 \\
\hline Overweight & 3 & 2.0 & 34 & 22.4 & 115 & 75.7 & 152 & 100 \\
\hline Light Obesity & 2 & 4.2 & 3 & 6.2 & 43 & 89.6 & 48 & 100 \\
\hline Obesity & 0 & 0 & 1 & 12.5 & 7 & 87.5 & 8 & 100 \\
\hline Morbid Obesity & 0 & 0 & 0 & 0 & 2 & 100 & 2 & 100 \\
\hline Total & 8 & 2.8 & 45 & 15.8 & 232 & 81.4 & 285 & 100 \\
\hline
\end{tabular}

According to Table 12, when we look at distributions of MET (Physical activity level) values of old individuals pursuant to their smoking habits, it has been seen that the highest percentage of smokers is "Active" MET with $77.0 \%$ ( $\mathrm{n}=107)$, and again the highest percentage of non-smokers is 
"Active" MET with 85.6\% ( $\mathrm{n}=125)$. This indicates that there is a meaningful significance statistically in the comparison of MET values pursuant to smoking habits.

According to Table 13, when we look at MET (Physical activity level) values of old individuals pursuant to their waist circumferences, it has been seen that the highest percentage of normal individuals is "Active" MET with 73.9\% ( $n=113)$, and again the highest percentage of the individuals, who have a risk of an illness is "Active" MET with $90.2 \%(n=119)$. A meaningful significance is found statistically in the comparison of MET values pursuant to waist circumferences of individuals according to table.

According to Table 14, when we look at distribution of MET (physical activity level) Values of elders pursuant to hip circumferences of old individuals, it has been seen that the highest percentages of individuals whose hip circumference is $44-48 \mathrm{~cm}$ is "Active" MET with $91.1 \%(\mathrm{n}=82)$, and again when we look at individuals whose hip circumference is $89-133 \mathrm{~cm}$, the highest percentage is "Active" MET with 76.1\% ( $\mathrm{n}=143)$, and when we look at individuals whose hip circumference is 134$178 \mathrm{~cm}$, the highest percentage is "Active" MET with $100 \%(n=5)$, and when we look at individuals whose hip circumference is $179-223 \mathrm{~cm}$, the highest percentage is "Active" MET with $100 \%$ ( $n=2)$. No meaningful significance is found statistically in the comparison of MET values pursuant to hip circumferences of individuals accordingly.

According to Table 15, when we look at distribution of MET (physical activity level) Values of elders pursuant to their Body Mass Indexes (BMI), it has been seen that the highest percentages of thin individuals is measured as "Active" MET with $91.1 \%(n=82)$, and again when we look at individuals with normal weight, the highest percentage is measured as "Active" MET with 86,5\% $(n=64)$, and when we look at individuals who are overweight, the highest percentage is measured as "Active" MET with 75.7\% ( $\mathrm{n}=115)$, and when we look at individuals with light obesity, the highest percentage is measured as "Active" MET with $89.6 \%$ $(n=43)$, and the highest percentage of individuals who have obesity is measured as "Active" MET with $87.5 \%(\mathrm{n}=7)$, and the highest percentage of individuals with morbid obesity is "Active" MET with $100 \%(n=2)$. No meaningful significance is found statistically in the comparison of MET values pursuant to Body Mass Indexes of individuals accordingly.

\section{DISCUSSION}

Many scientific studies indicate that Regular Physical Activity has positive benefits for the body throughout the entire life $(24,25,26,27)$.

One of the biggest opportunities brought by Physical Activity is to live independently, to decrease injuries and insufficiencies, to improve a quality life in middle ages and old ages for a long time. When evaluating life quality in elders, cognitive, emotional, social and physical functions must be assessed together (28). It is inevitable for individuals who are at the age of fifty and over to experience a pause in their business and social life. Thus, we have addressed physical activity levels of men at the age of fifty and over regarding the review of physical activity of individuals in our study.

Arabaci et al. Have found that the physical activities of single ladies or ladies who work for themselves are lower than the married ones (9) and in our study, a meaningful (difference) is found in the comparison of $\mathrm{AO}$ and MET values according to marital status. In this context, our studies show parallelism to each other.

In another study implemented by Arabac1 \& Korkmaz, 386 men test subjects between the ages of 18-69 have participated to their study in Bursa. $47.7 \%$ of the subjects have been stated as inactive, $30.4 \%$ as minimum active, and $21.9 \%$ as always active. As a result, they observed that physical activity levels of Turkish men who live in Bursa were insufficient and inactivity was common (29). However, this result is different from the data that we obtained as the result of our study.

In the studies of Genç et al. (30) related to "Research of Physical Activity and Life Quality Differences Between Male and Female Young Individuals", they stated that the intense activity, medium level activity, total physical activity, SF-36 physical and mental health scores in men were found higher than women. They stated that no meaningful significance was found statistically between lower, medium, high physical activity levels percentage values of men and women. In the study implemented by Genç et al., a meaningful significance is found statistically between all age groups (30), however, in the study that we have implemented, no meaningful significance is found statistically in the comparison of $\mathrm{AO}$ and MET values according to ages of men at the age of fifty 
and over. In this context, our studies show differences from each other.

In the study implemented by Korkmaz \& Deniz, they determined that there was no meaningful relationship between physical activity and education level (18), in the study that we have implemented, a meaningful significance is found between education level and physical activity. In this context, our studies show differences from each other.

In the study implemented by Pepe (31) on socio-economic levels of ladies who do exercise and do not exercise, it has been found that socioeconomic structure effects levels of participation to sports activity and the good facilities could not be indicated as a factor that encourages sports and bad facilities could not be indicated as a limiting factor. Soyuer et al. have determined in their studies on physical activity levels of old individuals that old individuals participate more physical activities than the young ones, and old women are more active than the old men, and as the income status and education levels rise the participation to activity was also increasing (3), and in our study, a meaningful significance is found statistically in comparison of $\mathrm{AO}$ and MET values according to income status. In this context, our studies show parallelism to each other.

In the study implemented by Savcr et al., no meaningful significance was found in respect of smoking and physical activity (32), and in our study, while there is no meaningful significance statistically in the comparison of $\mathrm{AO}$ values according to smoking habits, a meaningful significance is found in the comparison of MET values. In this context, our studies show differences from each other.

Arabac1 et al. (33) have found a meningful difference statistically in physical activity levels according to body mass indexes (BMI) of individuals in their study. In our study, no meaningful significance is found statistically in the comparison of MET values pursuant to Body Mass Indexes (BMI) of individuals. In this context, our studies show differences from each other.

As the result of studies that we have implemented, we can say that there is a relationship between AO values and marital status of old individuals to the detriment of married individuals, and this arises from single individuals having a more active life because of living by themselves. When we look at the relationship between education levels, income levels and AO and MET values, we can say that as the education and income level rises, old individuals live a more inactive life and as a result their $\mathrm{AO}$ and Waist circumferences increase.

According to World Health Organization (WHO), malnutrition, insufficient physical activity and obesity cause $10 \%$ of the life to be experienced with poor quality and fruitlessly more than the losses caused by cigarette (34). Life style plays an important role in reaching to healthy aging goals because it effects large society groups and consists of elements that cannot be changed. These elements can include nutrition, physical activity, cigarette and alcohol usage, sunbathing habit, participation to social activities, regular sleep habit. Most of the studies related to behavioral determinants of bad health is concentrated on smoking, malnutrition, physical inactivity and alcohol consumption, world health organization states that these reasons are responsible from one third of the chronic illness load of the world (35). When we review the relationship between smoking and MET values we can say that the non-smokers have a more active life and this is because they are more aware and careful about health.

\section{REFERENCES}

1. Ali E. Hypertension and Exercise. $13^{\text {th }}$ Sport Medicine Congress (16-18 December 2011), Bolu, Turkey.

2. Arabacı R, Korkmaz N. Study on the physical activity level of Turkish males. International Journal of Human Sciences. https:/www.insanbilimleri.com/ insanbil/ojs/index.php/uib/a rticle/view/532 2008.

3. Atay E, Hekim M. Yetişkin bireylerde bedensel etkinliğin sağlik üzerine etkileri. Uluslararası Hakemli Akademik Spor Sağlık Ve Tıp Bilimleri Dergisi, 2013: 07; 3.

4. Atay E, Hekim M. Yetişkin bireylerde bedensel etkinliğin sağlik üzerine etkileri. Uluslararası Hakemli Akademik Spor Sağlık ve Tıp Bilimleri Dergisi, 2013; 3(7): 113-122,

5. Aydın ZD. Toplum ve Birey için Sağlıklı Yaşlanma: Yaşam Biçiminin Rolü. Süleyman Demirel Üniversitesi Tıp Fakültesi Dergisi, 2006: 13(4); 43-48.

6. Ayrancı Ü, Köşgeroğlu N, Yenilmez Ç, Aksoy F. Eskişehir'de yaşlıların sosyo ekonomik özellikleri ve sağlık durumları. Sürekli Tıp Eğitim Dergisi (STED), 2005: 14(5): 113 -119.

7. Bayrakçı YV. Yetişkinlerde Fiziksel Aktivite. Ankara: Klasmat Matbaacilık, 2008.

8. Bilir N. Türkiye'de ve Dünyada Yaşlilarda Demografik Özellikler. Geriatri ve Gerontoloji. Arıoğlu S (editör). Ankara: M\&N Medikal Nobel, 2006: 3-10.

9. Birtane M, Tuna H, Ekuklu G. Edirne Huzurevi sakinlerinde yaşam kalitesine etki eden etmenlerin irdelenmesi. Geriatri, 2000; 3: 141-145.

10. Blair SN, Goodyear NN, Gibbons LW, Cooper KN. Physical fitness and incidence of hypertansyon in healthy 
normottensive men and women. J Am Med Assoc, 1990: 252: 487-490.

11. Craig CL, Marshall AL, Sjostrom M, Bauman AE, Booth ML, Ainsworth BE, Pratt M, Ekelund U, Yngves A, Sallis JF, Oja P. International Physical Activity Questionnaire: 12-country reliability and validity. Medicine \& Science in Sports \& Exercise, 2003: 0195-9131/03/3508-1381.

12. Durgun B, Tümerdem Y. Kentleşme ve yaşlilara sunulan hizmetler. Geriatri, 1999; 2(3):115-120.

13. Garner DM, Garfinkel PE, Schwartz D, Thompson M Cultural expectations of thinness in women. Psychological Reports, 1980; 47: 183-191.

14. Genç A, Şener Ü, Karabacak H, Üçok K. Kadin ve erkek genç erişkinler arasinda fiziksel aktivite ve yaşam kalitesi farkliliklarinın araştirılması. Kocatepe Tıp Dergisi, 2011; 12 145-150.

15. Haş1 Korkmaz N, Deniz M. Yetişkinlerin fiziksel aktivite düzeyleri ile sosyo-ekonomik düzeyleri arasindaki ilişkinin incelenmesi. E-Journal of New World Sciences Academy, http://dx.doi.org/10.12739/NWSA.2013.8.3.2B009.

16. Al S, Subaşı F, Mungan-Ay S. Yaşlıların fiziksel kapasitelerinin ve yaşam kalitelerinin değerlendirilmesi. Geriatri, 2003; 6: 95-99.

17. Karaca A. Ankara ilinde çalişan bireylerin bedensel etkinlik düzeyleri. Gazi Beden Eğitimi ve Spor Bilimleri Dergisi, 2000 5(3): 11-19.

18. Kayıhan G, Ersöz G. 15-18 yaş grubu adolesanlarda obezite tanisinda ve vücut yağ yüzdesinin belirlenmesinde kullanilan farkli yöntemlerin karşılaştırılması. Turkiye Klinikleri J Sports Sci, 2009; 1(2): 107-116.

19. Lee IM. Physical Activity, Fitness and Cancer. In: Bouchard, C, Shepard, RJ, Stephens, T, Eds. Physical Activity, Fitness and Health: International, Proceedings and Consensus Statement. Champaign IL. Human Kinetics, 1994: 814-831.

20. Manson JE, Rimm EB, Stampfer MJ. Physical activity and incidence of noninsulin dependent diabetes mellitus in women. Lancet, 1991; 338: 774-778.

21. Özdirenç M, Özcan A, Akın F, Gelecek N. Physical fitness in rural children compared with urban children in Turkey. Pediatrics International, 2005; 47(1): 26-31.

22. Öztürk M. Üniversitede eğitim-öğretim gören öğrencilerde uluslararasi fiziksel aktivite anketinin geçerliliği ve güvenirliği ve fiziksel aktivite düzeylerinin belirlenmesi. Yayınlanmamış Yüksek Lisans Tezi, Hacettepe Üniversitesi, Ankara, 2005
23. Pepe, K. Isparta ve Burdur İl merkezindeki lisansli sporcularin sosyo-ekonomik yapiları. Yüksek Lisans Tezi. Isparta: Süleyman Demirel Üniversitesi, Sosyal Bilimler Enstitüsü, 1998

24. R. Arabacı, Çankaya C. Beden eğitimi öğretmenlerinin fiziksel aktivite düzeylerinin araştirilmasi. Eğitim Fakültesi Dergisi, 2007; XX(1): 1-15.

25. Salonen JT, Puska P, Toumilehto J. Physical activity and risk of myocardial infarction, celebral stroke and death: A longitudinal study in Eastern Finland. Am J Epidemiol, 1982; 115:526-537.

26. Savcı S, Öztürk M, Arıkan H, İnalİnce D, Tokgözoğlu L. Üniversite öğrencilerinin fiziksel aktivite düzeyleri. Türk Kardiyoloji Derneği Arşivi, 2006; 34: 3.

27. Singh D. Body shape and women's attractiveness: the critical role of waist-to-hip ratio. Human Nature, 1993; 4: 297- 321.

28. Soyuer F, Soyuer A. Yaşlılık ve fiziksel aktivite. İnönü Üniversitesi Tıp Fakültesi Dergisi, 2008; 15(3): 219-224.

29. Tessier S, Vuillemin A, Bertrais S, Boini S, Bihan EL, Oppert JM, Hercberg S, Guillemin F, Briançon S. Association between leisuretime physical activity and health-related quality of life changes over time. Preventive Medicine, 2007; 44(3): 202-208.

30. Türkiye Fiziksel Aktivite Rehberi. 2.Baskı, Kuban Matbaacilık Yayıncılık, Yayın No: 940, Ankara, 2014.

31. Vural Ö, Eler S, Atalay Güzel N. Masabaşi çalişanlarda fiziksel aktivite düzeyi ve yaşam kalitesi ilişkisi. Spormetre Beden Eğitimi ve Spor Bilimleri Dergisi, 2010; 8(2): 69-75.

32. Vural Ö. Masabaşi çalişanlarda fiziksel aktivite düzeyi ve yaşam kalitesi ilişkisi. Yüksek Lisans Tezi, Ankara; Gazi Üniversitesi, Sağllk Bilimleri Enstitüsü, Beden Eğitimi ve Spor Anabilim Dalı,2010.

33. Welk GJ, Meredith MD. Factors that influence physical fitness in children and adolescents. (Pangrazi RP, Corbin CB, eds). Fitnessgram/ Activity Gram Reference Guide. 3rd Ed. pp. 5260. Dallas, TX, The Cooper Institute Pub,2008.

34. Yıldırım M, Akyol A, Ersoy G. Şişmanlık (obezite) ve fiziksel aktivite. T.C. Sağlık Bakanlığı, Türkiye Halk Sağlığı Kurumu, Obezite Diyabet ve Metabolik Hastalıklar Dairesi Başkanlığı, Ankara, Yayın No: 2012:729.

35. Yonca B. Düzenli egzersizin kalp damar hastaliği olan kadin hastalarin vücut kompozisyonlari üzerindeki etkileri. eJournal of New World Sciences Academy, 2009; 4: 2. 